\title{
Femtosecond laser-assisted lamellar keratoplasty
}

\author{
Transplante lamelar auxiliado pelo laser de fentosegundo
}

\author{
Hunson KazSoong' \\ João Baptista Nig'ro Santiago Malta² \\ Shahzad Ihsan Mian ${ }^{3}$ \\ Tibor Juhasz ${ }^{4}$
}

\begin{tabular}{|l|}
\hline ABSTRACT \\
\hline Lamellar keratoplasty consists of transplanting partial-thickness donor \\
cornea onto a complementary recipient bed. Manual lamellar dissection is \\
technically very difficult, time-consuming, and imprecise. Also, the ma- \\
nually-dissected lamellar interface often has topographical irregularities \\
that may optically degrade the best-corrected visual acuity. The femto- \\
second clinical laser(IntraLase FS Laser ${ }^{\mathrm{TM}}$ Irvine, CA) is a recent innovation \\
that can be programmed to produce bladeless, precise lamellar cuts at any \\
depth with accompanying trephination cuts for both anterior and posterior \\
lamellar transplantion. Posterior laser cuts may be used to assist in deep \\
lamellar endothelial keratoplasty or Descemet's stripping automated en- \\
dothelial keratoplasty.
\end{tabular}

Keywords: Cornea/cirurgia; Corneal transplantation/methods; Corneal transplantation/ instrumentation; Laser therapy/methods

\section{INTRODUCTION}

Penetrating keratoplasty (PKP) is the most common type of corneal transplant surgery currently performed. Although the final best-corrected visual acuity may be excellent after PKP, visual rehabilitation is often excruciatingly slow and frequently hampered by high and/or irregular astigmatism. The open-sky surgical exposure leaves very little protection should an expulsive choroidal hemorrhage occur intraoperatively. Postoperatively, even years after PKP, the full-thickness graft-host junction never heals to the original corneal strength. The large circumferential wound is thus an Achilles heel that is notoriously susceptible to traumatic dehiscence, often resulting in severe loss of vision.

Lamellar keratoplasty (LKP) consists of transplanting partial-thickness donor cornea onto a complementary recipient bed that has been dissected free of abnormal anterior or posterior stroma. Although the partial-thickness approach obviates many of the aforementioned complications of PKP, lamellar dissection remains technically demanding. With manual dissection, the lamellar interface often has clinically-significant topographical irregularities that optically degrade the best-corrected visual acuity by as much as one line on the Snellen chart ${ }^{(1)}$. These are some of the factors that contribute to the relatively low popularity of lamellar transplantation. With recent improvements in technology, however, the technical ease and visual outcomes of LKP have improved substantially. This will undoubtedly lead to an increase in the frequency of lamellar transplantation.

Currently, anterior LKPs are done mostly for optical and tectonic purpo$\operatorname{ses}^{(2-3)}$ in corneas with healthy endothelium. Specific optical indications for anterior LKPs include Reis-Bückler dystrophy of Bowman's layer, stromal dystrophies with predominantly anterior involvement, irregular anterior sur- 
face topography from disease or trauma, and occasionally keratoconus. Tectonic anterior LKPs are performed mainly for corneal ectasias, perforations, and descemetoceles, but may also be indicated for benign anterior corneal tumors and for pterygia covering the central visual axis.

In 1998, Melles et al. developed and refined the technique of posterior LKP, better known as deep lamellar endothelial keratoplasty or DLEK, as an alternative to PKP for corneal endothelial disease ${ }^{(4)}$. In DLEK, a thin lamellar disc or button of posterior stroma, together with the endothelium, is replaced with a similar sized posterior lamellar disc from a donor cornea ${ }^{(5)}$. Since then, several variants and refinements of this surgical technique have been reported ${ }^{(6-8)}$. DLEK, like anterior LKP, avoids many of the pitfalls of full-thickness PKP, such as high refractive errors, irregular astigmatism, anisometropia, corneal suture problems, the dangerous open-sky surgical approach, and the risk of postoperative wound dehiscence. Unfortunately, manual posterior lamellar dissection is technically very difficult, time-consuming, and imprecise.

Several blade microkeratome-assisted DLEK techniques have been developed in an attempt to facilitate the posterior lamellar dissection and to improve the smoothness of the lamellar interface ${ }^{(9-11)}$. The femtosecond clinical laser (IntraLase FS LaserTM, Irvine, CA) ${ }^{(12)}$ is yet another innovation that can be programmed to produce bladeless corneal lamellar cuts at any depth with accompanying trephination cuts of desired diameters in both anterior LKP and posterior LKP. This laser may also be used for donor tissue cutting in Descemet's stripping automated endothelial keratoplasty (DSAEK), significantly reducing its technical difficulty and improving the cut precision $^{(13-17)}$.

\section{Femtosecond laser background information}

The femtosecond laser is a focusable, near-infrared $(1053 \mathrm{~nm})$ laser that generates ultrashort pulses in the femtosecond $\left(10^{-15}\right.$ second) range. This is similar to the more common Nd:YAG laser, which uses pulses in the nanosecond $\left(10^{-9}\right.$ second $) \mathrm{du}-$ ration range. When the pulse duration is shortened from the nanosecond to the femtosecond time domain, the energy required for producing tissue breakdown is also reduced. This, in turn, minimizes collateral tissue damage and inflammation $^{(18-21)}$, and thermal damage to the surrounding tissue is confined to less than $1 \mu \mathrm{m}^{(22)}$. Through a process known as photodisruption, the femtosecond laser vaporizes small volumes of tissue, generating a plasma of rapidly-expanding hot ionic gases. The resulting shock wave is followed by formation of a cavitation bubble $\left(\mathrm{CO}_{2}\right.$ and $\left.\mathrm{H}_{2} \mathrm{O}\right)$, which in the cornea, eventually escapes through the surrounding stromal tissue.
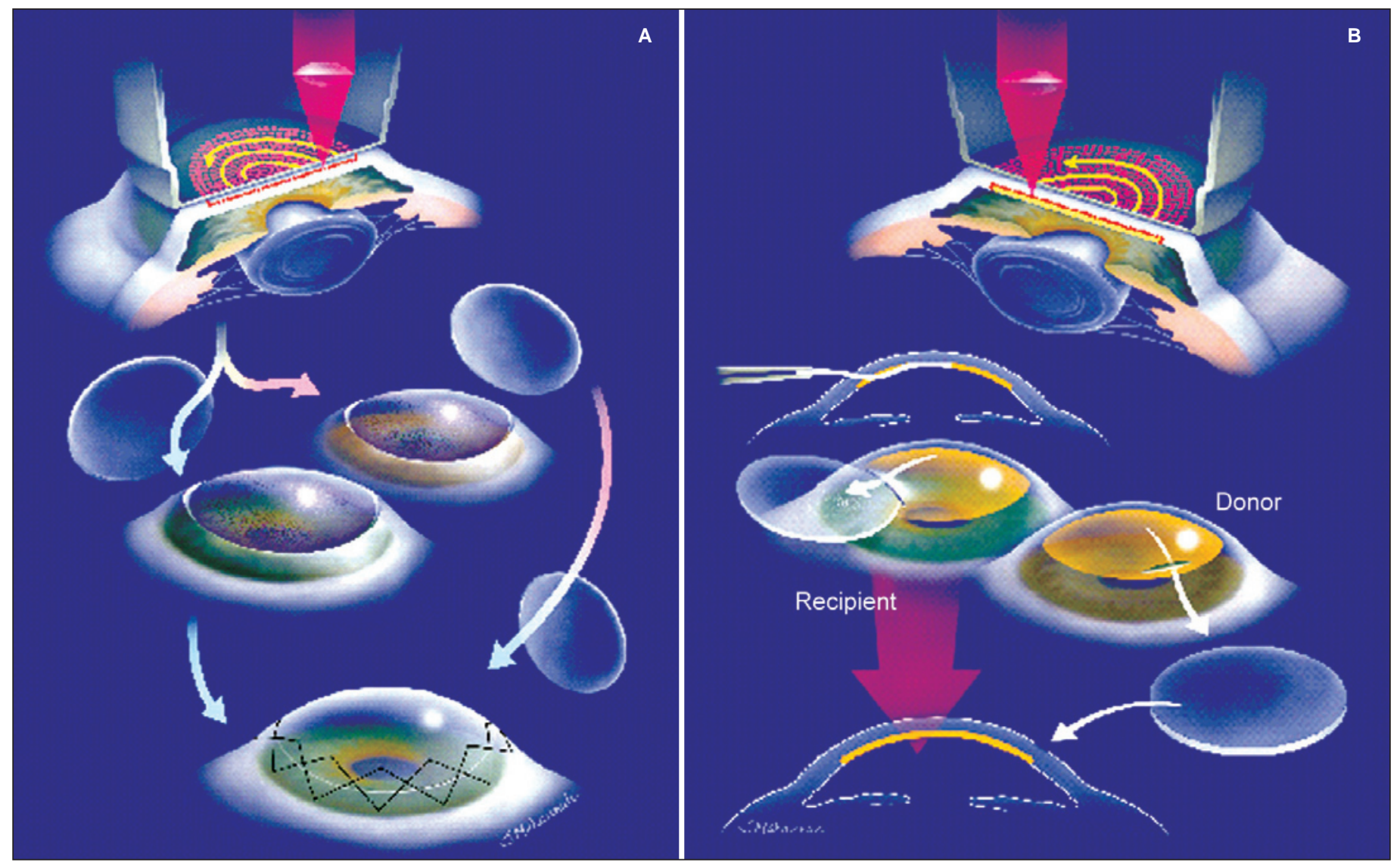

Figure 1 - Schematic diagram illustrating femtosecond laser-assisted (A) anterior LKP and (B) DLEK 
With precise computer-controlled laser energy, spot size, spot separation, and firing pattern, the IntraLase FS Laser is is capable of cutting lamellar, axial, or pocket cuts at different desired depths and diameters in the cornea. The laser spots may be fired in an expanding spiral pattern or a zigzag (raster) pattern to achieve the lamellar incisions. Unlike lasers that employ visible wavelengths, the ability of the femtosecond laser to cut cornea is less affected by its cloudiness, making it ideal for treating edematous corneas. Currently, the FS-Laser ${ }^{\mathrm{TM}}$ is gaining popularity in the United States as a safer alternative to the mechanical microkeratome for creating LASIK flaps, and has been reported to produce good visual outcomes and a low flap-complication rate ${ }^{(12)}$. In the FS Laser, hinge option may be easily turned off in the software to create a controlled anterior free cap for anterior LKP or a circular posterior button for DLEK and DSAEK.

Femtosecond laser treatment of the cornea requires a lowsuction $(35 \mathrm{mmHg})$ applanating lens to immobilize the eye and to flatten the anterior cornea to allow treatment of a geometrically simple planar structure ${ }^{(23)}$. Recently, a curved applana- ting lens is being investigated by IntraLase Corporation as an alternative to the planar lens.

\section{Femtosecond laser-assisted anterior LKP}

For anterior LKP, the FS Laser ${ }^{\mathrm{TS}}$ is programmed to produce anterior lamellar and trephination cuts at the desired depth and diameter. The standard applanating lens used to create LASIK flaps is also used in laser-assisted anterior LKP. Laser treatment begins with formation of the lamellar cut at a depth determined by the corneal opacities (Figures 1A and 2). The anterior trephination cut (6.0-8.0 mm diameter) is then performed by programming a circular pattern of contiguous laser spots to sequentially move anteriorly, starting at the plane of the lamellar interface and ending slightly anterior to the corneal epithelium. For most anterior LKPs, the energy setting for the lamellar interface and the trephination cuts are similar to those used in LASIK, i.e., $3.3 \pm 0.1 \mu \mathrm{J}$ and $4.0 \pm 0.1 \mu \mathrm{J}$, respectively. Trephination requires slightly higher energy levels than lamellar incisions since the cuts are across, rather than along, the
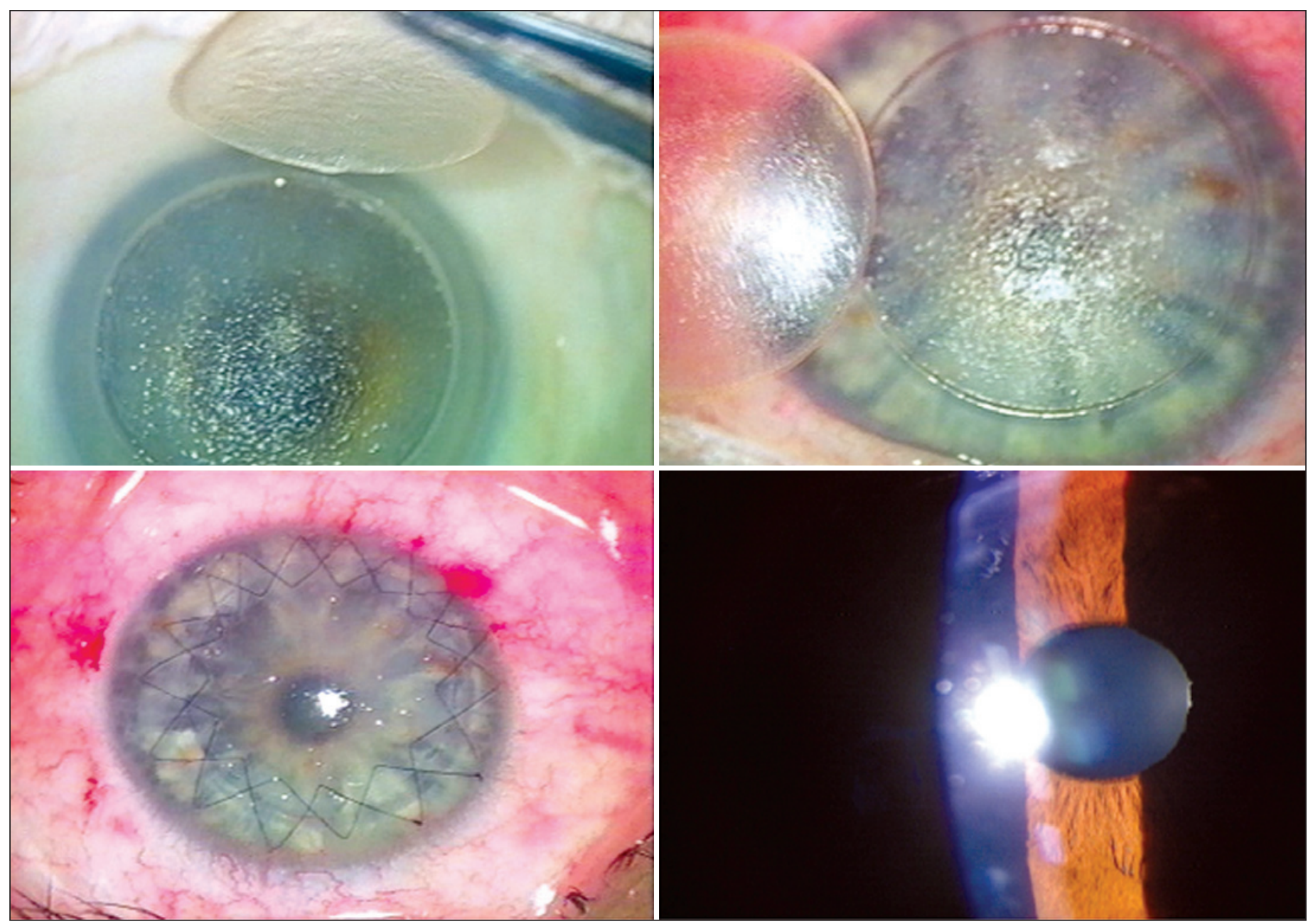

Figure 2 - Femtosecond-assisted anterior LKP. Top left. Anterior corneal cap removed from donor whole globe, showing smooth stromal surface. Top right. Anterior corneal cap excised from host eye, showing smoothness of deep lamellar bed. Bottom left. Donor graft secured to recipient bed with double-running sutures. Bottom right. Postoperative slit-lamp biomicroscopic appearance of anterior LKP at 3 months. 
stromal fibers. The laser spot size is set for 2.0-2.4 $\mu \mathrm{m}$ and the pulse delivery rate is $30-60 \mathrm{kHz}$. For deeper anterior LKPs, the laser energy levels could be set higher and the spot separation closer in order to overcome laser scatter and attenuation caused by the additional thickness of stroma. The donor cornea (from either a whole globe or a corneoscleral button on an artificial anterior chamber) is treated in an identical fashion.

The anterior lamellar buttons are separated from the corneas in both the host and donor by sweeping the lamellar interface with a Barraquer iris sweep to break the remaining bridges of uncut stroma. The donor anterior lamellar corneal button is transferred into the host lamellar bed and sutured with either interrupted or running 10-0 nylon sutures.
The femtosecond laser is also currently being used in anterior LKP to prepare both donor button and recipient corneal bed in "all-laser" sutureless lamellar keratoplasty (ALSL$\mathrm{LK})^{(24)}$. In this procedure, the edges of the lamellar wound are welded with diode-laser-induced adhesion, thus obviating conventional sutures.

\section{Femtosecond laser-assisted DLEK and DSAEK}

Femtosecond laser-assisted DLEK techniques (Figure 1B) and results in human eye bank eyes have been reported ${ }^{(17,25-27)}$. The laser treatment sequence for DLEK and DSAEK is programmed in the reverse of anterior LKP; namely, the trephination cut precedes more anterior lamellar treatment. This avoids

A

\section{Cross-Sectional Schematic Diagram of Laser Cuts}
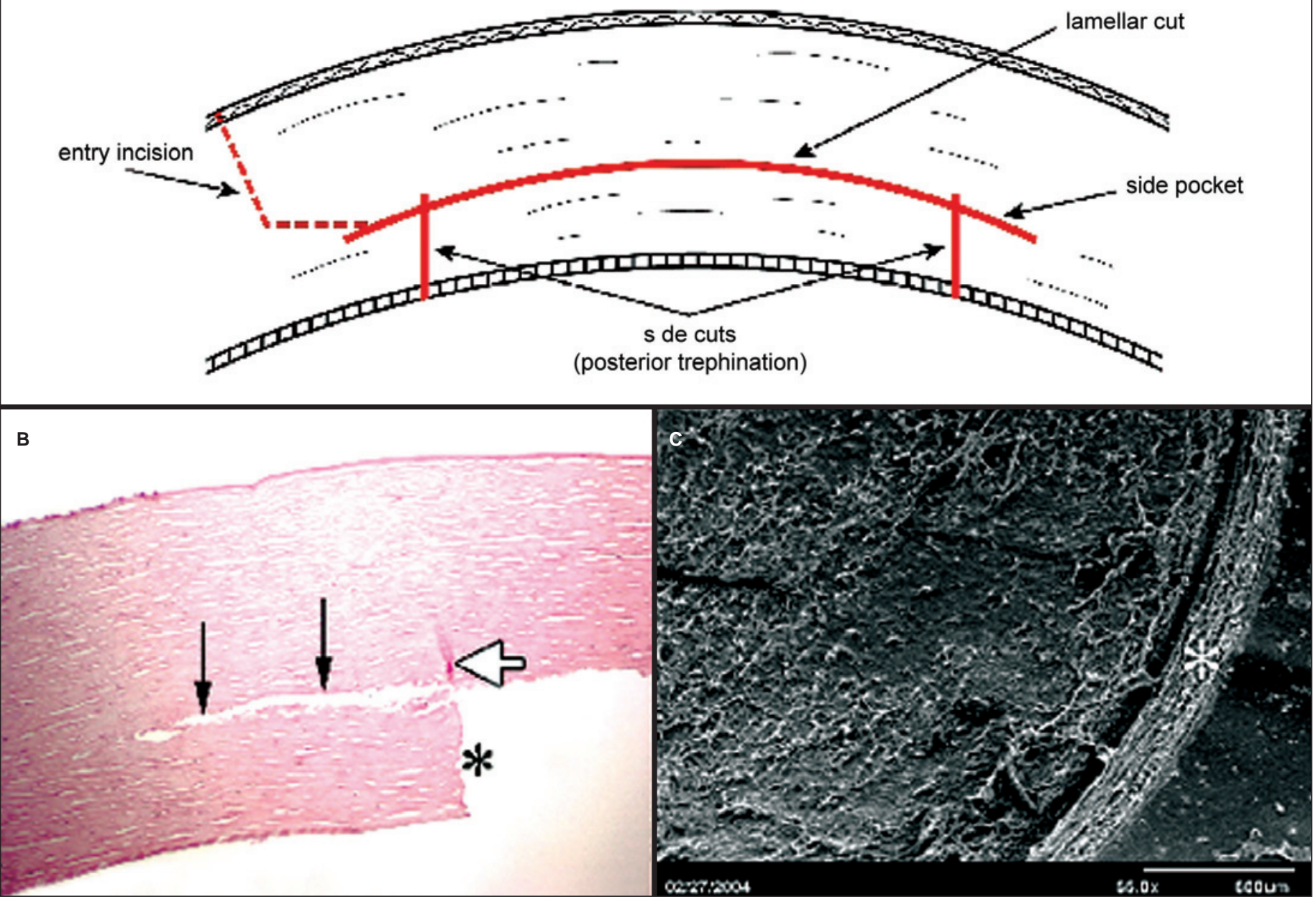

Figure 3 - (A) Schematic cross-sectional view of lamellar and trephination cuts (solid red lines) in laser-assisted DLEK. Peripheral corneal (or scleral) tunnel incision (dotted red lines) is made with blade or laser. Lamellar bed may be oversized peripherally, to ensure intersection of lamellar and trephination cuts, and to produce side pockets into which donor button edge may be secured, (B) Cross-sectional histologic specimen of femtosecond laser trephination edge $\left(^{\star}\right)$, lamellar cut, and side pocket (black arrows). Minimal collateral laser damage visible on trephination cut (white arrow). Trephination cut extends anteriorly beyond lamellar cut to ensure intersection of cuts. (Hematoxylin-eosin stain in human cornea; original magnification, $\times 75)$ and $(C)$ Scanning electron micrograph of lamellar interface and cross-sectional edge of trephination cut $(*)$ in DLEK. (original magnification, $\times 56$ ). 
the lamellar treatment cavitation bubbles from blocking laser energy to the subsequent posterior trephination. A custommade short applanating lens must be used instead of the standard applanating lens that is designed to create LASIK flaps and anterior LKP buttons. The shorter focal length allows the laser to be focused at a deeper planes than in LASIK and anterior LKP. The laser spot size is set to $2.4 \mu \mathrm{m}$ and the laser pulse delivery rate is $30-60 \mathrm{kHz}$.

In DLEK the posterior trephination (6.0-8.0 $\mathrm{mm}$ diameter) begins in the anterior chamber and progressively moves anteriorly through endothelium, Descemet's membrane, and posterior stroma. To assure complete cuts deep inside edematous corneas, higher trephination energy levels $(8.7 \pm 0.1 \mu \mathrm{J})$ than in anterior LKP may be used. The lamellar plane is then cut at about 150 to $200 \mu \mathrm{m}$ anterior to the endothelial surface (Figure $3 \mathrm{~A})$, using a slightly lower energy $(7.4 \pm 0.1 \mu \mathrm{J})$ than the trephination cut. The donor corneal button in both DLEK and DSAEK is cut from either a whole globe or a corneoscleral button on an artificial anterior chamber. The diameter of the lamellar dissection is intentionally made 1.0 to $2.0 \mathrm{~mm}$ larger than the trephination diameter (Figure 3A), in order to ensure that these two cuts meet. This allows the cavitation bubbles to escape into the anterior chamber and the posterior disc to be easily separated from the peripheral edges. Also, a lamellar side pocket (Figure $3 \mathrm{~A}$ ) created by this oversizing allows the peripheral edges of the donor disc to be tucked securely into the recipient bed in DLEK.

The lamellar interface is entered from the anterior surface of either cornea or sclera via either a $4 \mathrm{~mm}$-wide freehand tunnel incision or a similar laser-cut tunnel incision. The stromal bridges in the lamellar interface are easily swept apart with a Barraquer iris sweep and the posterior corneal button is removed through the tunnel incision with Utrata capsulorrhexis forceps.

In DLEK and DSAEK, the donor button is folded tacostyle with the endothelial side in, protected by a layer of viscoelastic material, and inserted through the tunnel incision into the anterior chamber with Utrata forceps. The graft button is unfolded in the anterior chamber after carefully ascertaining correct orientation of the endothelial face. Viscoelastic material in the anterior chamber is exchanged with balanced-salt solution and an air bubble is injected into the anterior chamber to pneumatically tamponade the donor disc into place. The small tunnel incision may be sutured if desired. Light-microscopic histologic studies of the laser-cut corneas show smooth lamellar stromal cuts with straight trephination edges (Figure 3B). Scanning electron microscopic studies show a mild stucco-like texture of the lamellar surface and a crisp trephination edge (Figure 3C). This mild stucco texture may actual aid in adhesion of the button in DLEK and DSAEK. Clinical slitlamp examination in a live rabbit at one month and six months postoperatively shows a clear and compact central cornea with the posterior graft in excellent position, ringed by haze in the surrounding recipient cornea (Figure 4$)^{(28)}$.

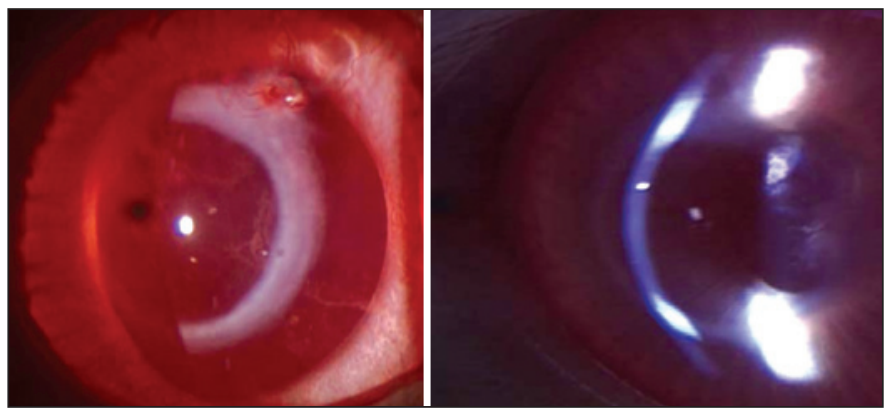

Figure 4 - In-vivo post-DLEK clinical appearance of cornea in rabbit at: Left. One month. Right. Six months. Note clear and compact central cornea with posterior graft in good position, surrounded by ring of haze in recipient corneal side pocket (into which graft edge is secured).

\section{CONCLUSIONS}

The bladeless femtosecond laser-assisted anterior LKP, posterior LKP, and DSAEK offer an exciting alternative to their manual and microkeratome-assisted counterparts. Femtosecond laser-assisted anterior LKP has already been performed in humans with good visual outcomes (IntraLase Corporation internal memorandum; Lee Nordan, M.D.), whereas the femtosecond-assisted DLEK technique requires further laboratory refinement and investigation before human clinical trials are conducted. The femtosecond laser is also currently being used at some centers in the cutting of the donor posterior corneal buttons in DSAEK surgery ${ }^{(15,29)}$ and for trephining complex, interlocking cuts in full-thickness PKP (personal communication: Roger Steirnert, MD and Francis Price, MD).

\section{RESUMO}

A ceratoplastia lamelar consiste em transplante de espessura parcial da córnea doadora em um leito receptor complementar. A dissecção lamelar manual é técnica de difícil realização, imprecisa e que demanda tempo. Além disso, a interface lamelar freqüentemente apresenta irregularidade topográfica que pode comprometer a acuidade visual final. O laser clínico "femtosecond" (IntraLase FS Laser ${ }^{\mathrm{TM}}$, Irvine, CA) é uma recente inovação que pode ser utilizado para produzir cortes lamelares precisos em qualquer profundidade da córnea, acompanhados de cortes verticais tanto para transplantes lamelares anteriores como posteriores sem a utilização de lâminas. Os cortes posteriores podem ser utilizados para a realização de ceratoplastia endotelial lamelar profunda ou ceratoplastia endotelial com remoção da membrana de Descemet.

Descritores: Córnea/cirurgia; Transplante de córnea/métodos; Transplante de córnea/instrumentação; Terapia a laser/métodos

\section{REFERENCES}

1. Soong HK. Corneal transplantation. In: Spaeth GL, editor. Ophthalmic surgery: principles and practice. Philadelphia, PA: Saunders; 2003. p.139-60. 
2. Soong HK, Katz D, Farjo AA, Sugar A, Meyer RF. Central lamellar keratoplasty for optical indications. Cornea. 1999;18(3):249-56.

3. Soong HK, Farjo AA, Katz D, Meyer RF, Sugar A. Lamellar corneal patch grafts in the management of corneal melting. Cornea. 2000;19(2):126-34.

4. Melles GR, Eggink FA, Lander F, Pels E, Rietveld FJ, Beekhuis WH, Binder PS. A surgical technique for posterior lamellar keratoplasty. Cornea. 1998;17(6):618-26.

5. Melles GR, Lander F, van Dooren BT, Pels E, Beekhuis WH. Preliminary clinical results of posterior lamellar keratoplasty through a sclerocorneal pocket incision. Ophthalmology. 2000;107(10):1850-6; discussion 1857.

6. Terry MA, Ousley PJ. Replacing the endothelium without corneal surface incisions or sutures: the first United States clinical series using the deep lamellar endothelial keratoplasty procedure. Ophthalmology. 2003;110(4):755-64; discussion 764. Comment in: Ophthalmology. 2004;111(1):193; author reply 194-5.

7. Terry MA, Ousley PJ. Endothelial replacement without surface corneal incisions or sutures: topography of the deep lamellar endothelial keratoplasty procedure. Cornea. 2001;20(1):14-8.

8. Terry MA, Ousley PJ. Rapid visual rehabilitation after endothelial transplants with deep lamellar endothelial keratoplasty (DLEK). Cornea. 2004;23(2):143-53.

9. Ehlers N, Ehlers H, Hjortdal J, Moller-Pedersen T. Grafting of the posterior cornea. Description of a new technique with 12-month clinical results. Acta Ophthalmol Scand. 2000;78(5):543-6.

10. Azar DT, Jain S, Sambursky R, Strauss L. Microkeratome-assisted posterior keratoplasty. J Cataract Refract Surg. 2001;27(3):353-6.

11. Busin M, Arffa RC, Sebastiani A. Endokeratoplasty as an alternative to penetrating keratoplasty for the surgical treatment of diseased endothelium: initial results. Ophthalmology. 2000;107(11):2077-82.

12. Nordan LT, Slade SG, Baker RN, Suarez C, Juhasz T, Kurtz R. Femtosecond laser flap creation for laser in situ keratomileusis: six-month follow-up of initial U.S. clinical series. J Refract Surg. 2003;19(1):8-14.

13. Mian SI, Shtein RM. Femtosecond laser-assisted corneal surgery. Curr Opin Ophthalmol. 2007;18(4):295-9.

14. Sarayba MA, Maguen E, Salz J, Rabinowitz Y, Ignacio TS. Femtosecond laser keratome creation of partial thickness donor corneal buttons for lamellar keratoplasty. J Refract Surg. 2007;23(1):58-65.

15. Cheng YY, Pels E, Nuijts RM. Femtosecond-laser-assisted Descemet's stripping endothelial keratoplasty. J Cataract Refract Surg. 2007;33(1):152-5.

16. Suwan-Apichon O, Reyes JM, Griffin NB, Barker J, Gore P, Chuck RS. Microkeratome versus femtosecond laser predissection of corneal grafts for anterior and posterior lamellar keratoplasty. Cornea. 2006;25(8):966-8.
17. Terry MA, Ousley PJ, Will B. A practical femtosecond laser procedure for DLEK endothelial transplantation: cadaver eye histology and topography. Cornea. 2005;24(4):453-9.

18. Juhasz T, Kastis GA, Suárez C, Bor Z, Bron WE. Time-resolved observations of shock waves and cavitation bubbles generated by femtosecond laser pulses in corneal tissue and water. Lasers Surg Med. 1996;19(1):23-31.

19. Juhasz T, Djotyan G, Loesel FH, Kurtz RM, Horvath C, Bille JF, Mourou G. Applications of femtosecond lasers in corneal surgery. Laser Phys. 2000; 10(2):495-500.

20. Juhasz T, Frieder H, Kurtz RM, Horvath C, Bille JF, Mourou G. Corneal refractive surgery with femtosecond lasers. IEEE J Sel Top Quantum Electron. 1999;5(4):902-10.

21. Loesel FH, Niemz MH, Bille JF, Juhasz T. Laser-induced optical breakdown on hard and soft tissues and its dependence on the pulse duration: experiment and model. IEEE J Quantum Electron. 1996;32(10):1717-22.

22. Lubatschowski H, Maatz G, Heisterkamp A, Hetzel U, Drommer W, Welling H, Ertmer W. Application of ultrashort laser pulses for intrastromal refractive surgery. Graefes Arch Clin Exp Ophthalmol. 2000;238(1):33-9.

23. Ratkay-Traub I, Juhasz T, Horvath C, Suarez C, Kiss K, Ferincz I, Kurtz R. Ultra-short pulse (femtosecond) laser surgery: initial use in LASIK flap creation. Ophthalmol Clin North Am. 2001;14(2):347-55, viii-ix.

24. Menabuoni L, Pini R, Fantozzi M, Susini M, Lenzetti I, Yoo SH. All-Laser Sutureless Lamellar Keratoplasty (ALSL-LK): A First Case Report. In: ARVO (Association for Research in Vision and Ophthalmology) Annual Meeting. 2006 Abr 30 Maio 4. Fort Lauderdale, FL, USA; 2006.

25. Seitz B, Langenbucher A, Hofmann-Rummelt C, Schlötzer-Schrehardt U, Naumann GO. Nonmechanical posterior lamellar keratoplasty using femtosecond laser (femto-plak) for corneal endothelial decompensation. Am J Ophthalmol. 2003;136(4):769-72.

26. Soong HK, Mian S, Abbasi O, Juhasz J. Femtosecond laser-assisted posterior lamellar keratoplasty: initial studies of surgical technique in eye bank eyes. Ophthalmology. 2005;112(1):44-9.

27. Sarayba MA, Juhasz T, Chuck RS, Ignacio TS, Nguyen TB, Sweet P, Kurtz RM. Femtosecond laser posterior lamellar keratoplasty: a laboratory model. Cornea. 2005;24(3):328-33.

28. Mian SI, Soong HK, Patel SV, Ignacio T, Juhasz T. In vivo femtosecond laserassisted posterior lamellar keratoplasty in rabbits. Cornea. 2006;25(10):1205-9.

29. Sikder S, Snyder RW. Femtosecond laser preparation of donor tissue from the endothelial side. Cornea. 2006;25(4):416-22. 